\title{
A Study of Tourism Satisfaction and Destination Image for Leisure Travelers Who Use Macau Low-Cost Carriers
}

\author{
Xin Wang ${ }^{1}$, Chia Hsin Leou ${ }^{1} \&$ Jiayi $\mathrm{Li}^{2}$ \\ ${ }^{1}$ Faculty of International Tourism and Management, City University of Macau, Macau \\ ${ }^{2}$ MBA-Accounting, School of Business, Johnson \& Wales University, United States \\ Correspondence: Xin Wang, Faculty of International Tourism and Management, City University of Macau, Edifício \\ Choi Kai Yau - N Building, $5^{\circ}$ Andar, Avda. Padre Tomás Pereira, Taipa, Macau.
}

Received: July 13, 2016

Accepted: July 28, 2016

Online Published: August 28, 2016

doi:10.5430/ijba.v7n5p1

URL: http://dx.doi.org/10.5430/ijba.v7n5p1

\begin{abstract}
The purpose of this study is to enhance the understanding of the relationship between the Low-Cost Carriers (LCC) leisure travelers' satisfaction and the destination images of Macau. Moreover, the researchers plan to provide suggestions for a sustainable development of Macau low-cost carriers. The LCC provide visitors planning to travel to Macau as the final destination cheaper and efficient choices. On the other hand, the LCC offer the visitors who were not selected Macau to be their final destination more economic prices and encourage them to take advantages of this transfer stop. The results of this study could provide a deep understanding of tourism satisfaction, destination image, tourist needs and behavior, factors that influence to repeat visiting, and what contribution could tourist made to Macau, those topics are deserve to be studied. Those outcomes were valuable reference to the air industry, Macau tourism industry, as well as Macau Government Tourism Office.
\end{abstract}

Keywords: tourism satisfaction, destination image, Macau low-cost carriers

\section{Introduction}

\subsection{Current Situation of Macau}

Macau has become known worldwide as the "Monte Carlo of the Orient" since Portuguese government legalized gambling in the colony in 1850s. The business has expanded rapidly since the government ended gambling monopoly in 2002, gambling became the biggest source of revenue in Macau. However, the business started grow slowly after June 2014, and related evaluate organizations like Morgan Stanley even predicted that revenue from gambling will be consistently reduce by $4 \%$ in 2005 . The fact reflects that gambling only cannot make contribution to sustainable development, Macau should come up a solution to establish a diverse industry of tourism. Back to 2009, some public voice had already raised a proposal about to create Macau as a "World's center of Leisure and Entertainment". However, The World Heritage Site, cultural tourism and other tourism attractions are not well-known comparing with gambling which has always been paying highly attention to.

On the other hand, according to the official data, the overall amount of visitors in 2014 had been increased. However, there are not sufficient data about visitors' consuming behavior, including mode of transportations, same-day visitors, hotel rooms' occupancy rate, per-capita spending of visitors, as well as tourism attractions.

Macau has a very unique geographical location with a competition of airports in Hong Kong, Guangzhou, Shenzhen, and Zhuhai which are also located around Pearl River Delta. Besides, Macau air transportation industry could still have a portion of market shares. In 2014, Macau International Airport had been awarded as one of the "Best Regional Airports in Asia", magazine Airway also reported that Macau International Airport had achieve a goal of a continuously rise of passenger capacities by 10\% annually in both year 2013 and 2014, which means the development of Macau air transport grows progressively. While, more research should be done to analyze the relationship between passenger capacities, number of visitors and other tourism attractions other than gambling.

As a matter of fact, assume visitors ignore considering the total travelling time, they would rather fly to airports of Hong Kong, Guangzhou, Shenzhen or Zhuhai first and then chose another modes of transportation to Macau than fly directly to Macau based on the total travelling expenditure. Under this circumstances, Macau international Airport brought in Low-cost Carrier (LCC) constantly in recent years in order to not only expand airline operations but also 
improve its market efficiency to meet the most high-level standards in North Asia, so that Macau Airport could be more competitive to other neighborhood airports related to flight prices. LCC offers exclusive options for customers who plan to visit Macau, also LCC saves much more trouble that may happen during travelling. Because of the outstanding effort of bringing in LCC, Macau International Airport could win the honor of being one of the "Best Regional Airports in Asia". In conclusion, LCC make a remarkable contribution to the development of Macau Airport. However, there is no related analysis studying about what influences visitors could make by choosing LCC. To be more precisely, there is also no related studies focusing on these visitors who chose LCC become mode of transportation, their tourism behavior, and perceptions and influences after visiting the destinations. Besides, since gambling is now following a decelerating trend, Macau should pay more attention on create as a "World's center of Leisure and Entertainment" observe visitors' tourist motivation, looking for the impact of LCC could do to customers' motivations as well as destinations' public image to provide detailed and sufficient information for Macau Government Tourism Office.

\subsection{Macau Low-cost Carriers}

In July 5, 2004, the first flight of Thai Air Asia from Bangkok to Macau, represented Macau Airport entered the age of low cost airlines. Low-cost carriers, such as Tiger Air and Jet Star from Singapore, Cebu Pacific of Philippine opened their route to Macau one after another. Later on, Macau also established its first low-cost carrier Viva airlines. There are 29 airlines operating in Macau currently, of which the low-cost airlines are 15, responsible for half of the Macau aviation passenger transportation.

Table 1. Macau low-cost carriers list

\begin{tabular}{|c|c|c|c|c|}
\hline Airline Name & Owner Nation & $\begin{array}{c}\text { First Flight to } \\
\text { Macau(Year) }\end{array}$ & Flight Route & $\begin{array}{c}\text { Frequency/ } \\
\text { Week }\end{array}$ \\
\hline Air Asia & Malasia & 2004 & Bangkok/ChiengmaiPattaya/ & 63 \\
\hline Tai Wang Tiger Air & Singapo & 2014 & Taipei/Gaoxiong - Macao & 26 \\
\hline Jet Star & Singapo & - & Nha Trang/Da Nang - Macao & 14 \\
\hline Spring Airlines & China(mainland) & 2011 & Shanghai - Macao & 12 \\
\hline Cebu Pacific & Philipins & 2007 & Clark/Manila - Macao & 11 \\
\hline Tiger Air & Singapo & - & Singapore - Macao & 10 \\
\hline Jin Air & Kora & 2009 & Seoul - Macao & 7 \\
\hline Thai Smile & Thailand & 2012 & Bangkok - Macao & 7 \\
\hline Siam Air & Thailand & - & Bangkok - Macao & 7 \\
\hline JUNEYAO Air & China(mainland) & - & Shanghai - Macao & 6 \\
\hline Air BUSAN & Kora & 2012 & Busan - Macao & 3 \\
\hline T'way Airlines & Kora & - & - & 0 \\
\hline Eastar Jet & Kora & 2011 & - & 0 \\
\hline V Air & Tai Wang & 2015 & - & 0 \\
\hline Air Asia Zest & Philipins & - & - & 0 \\
\hline
\end{tabular}

(Data source: Information are collated from the official website of Macau International Airport, data statistics up to May 2016)

The departure cities of these low-cost carriers, are almost the major Asian cities, such as Beijing, Shanghai, Singapore, Manila, Kaohsiung, Taipei, Kuala Lumpur, Bangkok, Seoul, Incheon, Busan and so on. The passengers who take low cost airlines headed to Macau, a part of them take Macau as their final destination, for those passengers, low cost airlines provide them a cheaper and convenient choice; and for another part of passengers who had never planned travel to Macau, because of the cheaper tickets of low-cost carrier, push them travel to Macau or take the Macau as a transit. In terms of market share proportion, the biggest share of the southeast Asian market in Macau passengers, reached $32 \%, 40 \%$ in mainland China, and Taiwan is $28 \%$.

Macau is the first region to bring in low-cost carrier in area China, low-cost carriers has been promoted as differentiated marketing strategy over the years. So far, Macau has attracted 15 low-cost carriers around the world to put into operation, covering 22 destinations in Southeast Asia. Low-cost carriers have experienced more than ten years of development in Macau, it becoming mature, and be a kind of rigid demand in Macau. The success of 
low-cost carriers in Macau, and a considerable market share in Asian countries today, fully verified the successful strategic of LCC development. The strong policy support from mainland China provides a stable and powerful environment for the civil aviation industry in Macau, coupled with Macau's unique geographical location, making low cost airlines grow with Macau as a "World Tourism and leisure center" positioning together, bearing and attracts tourists of worldwide. After years of efforts, an increasing number of passenger take Macau as their tourism destination, passengers of low-cost carriers occupy $31 \%$ of the total. Low-cost carrier is a great power of generator for Macau's diversify economy development.

\subsection{Theoretical Background}

The history of low-cost carrier among Asia is not like the development in The United States and European countries which have more stories to tell (Gilbert, et al., 2001). It is playing a significant role of changing the situation of the entire air industry. Especially for excursions, LCCs are more competitive than full service airlines. Although there was a crush-landing accident happened to Air Asia in December, before that, it was one of the most profitable airlines in the world (Ricart, et al., 2005). Because low-cost carriers are promoting lower price to appeal to potential customers, so cost control is essential them. The majority of researches nowadays are focusing on the relationship between cost control and efficiency.

Some researchers (Lian, 2014), took the example as Malaysian low-cost carrier to discuss the satisfaction of LCC. The result found out that most customers believe that promotions in off-peak seasons represent low quality and low performance; however, they believe promotions in holiday seasons mean high performance. Since those visitors always having low expectations, positive altitude as well as active social connections, those factors contribute to a satisfied output. While crowded spaces and limited seats area always upset customers. Lower price only cannot win back customers again. Other research studied that awareness of consumers regarding marketing strategy of LCCs, the justify of lower price. Especially on the competition of the same flight routes, when airlines are focusing on how to win customers by lower the price, normally, it is not an effective strategy. On the contrary, LCCs should take mixed service, products, price, availability, public image and promotion events all those factors into consideration. Likewise, some other researchers studied the relationship between customers' loyalty and behavior of repeated purchase.

Customer satisfaction is a subjective measurement; it is an antecedent of increased market share, profitability and customer retention, and it is explained better through customers' purchase intention than through service quality (Baker, 2013). Studies have shown that satisfaction is strongly associated with repurchase intention (Yeoh \& Chan, 2011) and influences the purchase intention more strongly than service quality (Cronin \& Taylor, 1992). It depends on a variety of factors such as perceived service quality, mood, emotions, social interactions and other experience-specific subjective factors; product quality; price; situation factors; and personal factors (Rust \& Oliver, 1994; Zeithaml \& Bitner, 2001). This is vital to airlines that have a mix of tangibles and intangibles (Gursoy et al., 2005). Customer satisfaction with LCCs is based on performance factors and the overall experience. For example, affordability, visual attractiveness and the 'caring and tangible' dimension contribute significantly to the prediction of satisfaction (Ariffin et al., 2010). Consumer attitude and needs differ significantly in term of the service marketing mix (Charoensettasilp \& Wu, 2013), and an individual may focus differently on the service marketing mix. Hence, the service marketing mix - product, price, place, promotion, people/employee, process, physical evidence and presentation can presumably enhance customer satisfaction. Similarly, customers may be consuming similar services from different LCCs, but the degree of satisfaction and dissatisfaction varies among individuals. Customer satisfaction can be determined by identifying 'the important service attributes and measure customer's perception of those attributes and overall customer satisfaction' (Zeithaml \& Bitner, 2000: 76). Evidently, some customers may forgo certain service attributes for price, depending on the types of service and the significance of the service attribute. Factors such as convenience, price or availability may enhance satisfaction while not actually affecting consumer's perception of service quality.

As deregulation has created intense competition among airlines, focusing on quality and customer satisfaction is becoming vital (Baker, 2013). How customers are served will also affect their service experience and mood state. Understanding and satisfying customers' expectations and subsequently being different from competitors are important in the competitive low-cost business environment. It is imperative for LCCs to emphasize satisfaction as it influences their customers' behavioral intentions (Saha \& Theingi, 2009) and to analysis the behavior of existing and potential customers (Grigolon et al., 2012). In this context, the provision of excellent service quality and high customer satisfaction, especially what drives customer satisfaction and whether it influences the purchase intentions and induces repeat purchases, becomes the main issue and challenges facing LCCs. 
Destination image is defined as an expression of knowledge, impressions, prejudices, imaginations and emotional thoughts an individual has of a specific place (Kim \& Richardson, 2003). Raised by Beerli and Martin (2004a, 2004b) about characteristics of destination image are fully detailed, here divided into 9 parts: natural resources; regular infrastructures; tourism infrastructures; tourism leisure and entertainment; culture, history and arts; political and economic elements; natural environment; social environment; and local atmosphere. Several scholars and researchers have already verified the reasonability of this category by practice.

Hsu \& Song (2013) found out some photos reflecting the history, heritage, gambling, cuisine and hotels of Macau by searching the magazines published in Mainland China. Research done by Lee, et al., (2014) proved that perception of destination could be different between visiting before and after. What is more, there is a relationship between perception of destination and tourism satisfaction. Destination image is the key to determine destination marketing success or not (Crompton 1979). Because of these professional tourism agencies exist, for example, travel agency, airlines company, they could convey those news and information to the public, to some extent, agencies influence the perception of destination (Hanefors \& Mossberg, 2002).

\section{Methodology and Research Design}

\subsection{Research Objectives}

The satisfaction on individuals travelling to Macau will influence the visitors' destination image during the visiting. For visitors planning to travel to Macau as the final destination, low-cost carriers provide them cheaper and efficient choices; for other visitors who will not chose Macau to be the final destination, LCC also provide them more economic prices fly to Macau and encourage them to take advantage of this transfer stop.

According to the topics talking above, like Tourist motivation, Destination image, tourist needs and behavior, factors that influence to repeat visiting, and what contribution could tourist made to Macau, those topics are deserve to be studied. Those studies are valuable reference to air industry, Macau tourism industry, as well as Macau Government Tourism Office.

The research objectives are:

I. To identify the perceptions of LCCs' passengers towards Macau's image.

II. To examine the differences of the LCCs' passengers' perceptions after they visit Macau.

III. To make recommendations to the marketers in Macau for uplifting the service quality.

\subsection{Method}

Methodology will be introduced into three parts:

I. Experts' interviews: discuss the recent situation of tourism resources in Macau and development in the future as well as the trend and existing concerns by holding experts' interviews. Bring comments and suggestion after discuss the available resources to help Macau tourism industry following a sustainable development direction.

II. Questionnaires: prepare sample tests among LCC passengers. Gathering information about LCC passenger regarding population features, purpose of visiting Macau, and major tourism resources would be visited after arrival as well as the role they are playing to transmitting destination image.

III. Statistical Analysis: analyze data gathering as primary source. Help design tourism plans and comments on perception of destination and destination image popularization.

\section{Results}

\subsection{Data Collection}

In order to target completion of this study, a survey was conducted in Macau international airports on a sample of tourists intercepted in the international departure area before leaving Macau. Interviews were made over 3 weeks during May/June 2016, and respondents were identified via convenience sample survey (Non-random systematic sample) by trained graduate students supervised by two of the coauthors. According to the sampling procedure, interviewers were located in the international departure terminals of the Macau airport, and a preliminary question served to exclude Macau citizens and to select respondents who had visited Macau for leisure purposes. Interviews were conducted with a face-to-face method.

\subsection{Analytical Method}

Excel, Statistical product and service solutions (SPSS) 21.0, and analysis of moment structure (AMOS) 21.0 were used to analyze the data. The analytical method included reliability analysis, validity analysis. 


\subsection{Findings and Discussions}

\subsubsection{Demographic Characteristics of the Sample}

In the sample, the proportion of males and females are rather equivalent to each other, accounting for $47.5 \%$ and $52.5 \%$, respectively. The results of this study show that respondents are mainly within the age group of 18-24 years old which accounts for 55.9\%, followed by the age group of 25-44 years old and that of 45-59 years old, accounting for $22 \%$ and $16.8 \%$, respectively. In terms of the occupation, the following three types hold a relatively higher proportion, namely, other occupations $(20.7 \%)$, private owners $(15.7 \%)$ and students $(14.2 \%)$. In the sample surveyed in this study, the proportion of tourists from Taiwan is the highest (36.2\%), followed by Mainland China (30.1\%) and others (26.5\%). As for the educational level, the biggest group among the tourists, accounting for $46.5 \%$, is the one who have achieved their Bachelor degree. In respect of the monthly income before tax, $38.6 \%$ of the tourists earn a monthly income before tax less than MOP 5000 and the tourists who earn a monthly income before tax between MOP 5000 and MOP 10000 rank second, having a proportion of $30.2 \%$.

Table 2. Demographic characteristics of sample $(\mathrm{N}=381)$

\begin{tabular}{|c|c|c|c|}
\hline $\begin{array}{l}\text { Demographic } \\
\text { Characteristics }\end{array}$ & Options & Frequency & $\%$ \\
\hline \multirow[t]{4}{*}{ Age, years } & $18 \sim 24$ & 213 & 55.9 \\
\hline & $25 \sim 44$ & 84 & 22.0 \\
\hline & $45 \sim 59$ & 64 & 16.8 \\
\hline & $\geq 60$ & 20 & 5.2 \\
\hline \multirow[t]{4}{*}{ Source of tourists } & China Mainland & 115 & 30.1 \\
\hline & Hong Kong & 27 & 7.1 \\
\hline & Taiwan & 138 & 36.2 \\
\hline & Other & 101 & 26.5 \\
\hline \multirow[t]{2}{*}{ Marital status } & Married & 97 & 25.5 \\
\hline & Single & 284 & 74.5 \\
\hline \multirow[t]{6}{*}{ Educational level } & Primary school & 6 & 1.6 \\
\hline & Junior middle school & 17 & 4.5 \\
\hline & Senior high school or Technical secondary school & 63 & 16.5 \\
\hline & Junior college & 71 & 18.6 \\
\hline & University or College & 177 & 46.5 \\
\hline & Master or above & 47 & 12.3 \\
\hline Monthly income & $\leq 5000$ & 147 & 38.6 \\
\hline \multirow[t]{4}{*}{ before tax, MOP } & $5001 \sim 10000$ & 115 & 30.2 \\
\hline & $10001 \sim 15000$ & 51 & 13.4 \\
\hline & $150001 \sim 20000$ & 28 & 7.3 \\
\hline & $\geq 20000$ & 40 & 10.5 \\
\hline \multirow[t]{10}{*}{ Occupation } & Government staff & 25 & 6.6 \\
\hline & Private owner & 60 & 15.7 \\
\hline & Student & 54 & 14.2 \\
\hline & Clerk & 45 & 11.8 \\
\hline & Teacher & 10 & 2.6 \\
\hline & Worker & 20 & 5.2 \\
\hline & Retiree & 23 & 6.0 \\
\hline & Freelance & 57 & 15.0 \\
\hline & Unemployed & 8 & 2.1 \\
\hline & Other & 79 & 20.7 \\
\hline
\end{tabular}

Note: Macau pataca $\$ 8=$ US $\$ 1$

\subsubsection{Analysis of Tourism Satisfaction, Cognitive City Image and Destination Image}

Three parts in questionnaire survey: The first part is the survey about satisfaction of details in different delicacy activities. Interviewees will rate on a scale of 5 to 1: 5 mark represent 'strongly agree', 1 mark stand for 'strongly 
disagree', et cetera. The second part is the survey about cognitive city image, interviewees will rate on a scale of 5 to 1: 5 mark represent 'strongly agree', 1 mark stand for 'strongly disagree', et cetera. The third part is destination image, list these suggestions to interviewees and ask them rate on a scale of 5 to $1: 5$ mark represent 'strongly agree', 1 mark stand for 'strongly disagree', et cetera.

Table 3. Validity check

\begin{tabular}{|c|c|c|c|c|}
\hline & $\begin{array}{l}\text { Mean } \\
\text { (standard } \\
\text { deviation) }\end{array}$ & $\begin{array}{l}\lambda \text { Scores } \\
\text { (standard } \\
\text { solution) }\end{array}$ & $\begin{array}{l}\text { Cronbach's } \\
\alpha\end{array}$ & AVE \\
\hline Tourism satisfaction & & & 0.81 & 0.52 \\
\hline In general, I'm very satisfied with this travel experience in Macau & $3.74(0.59)$ & & & \\
\hline $\begin{array}{l}\text { This travel experience definitely exceeded my expectations in terms } \\
\text { of overall quality and satisfaction }\end{array}$ & $3.54(0.63)$ & & & \\
\hline $\begin{array}{l}\text { In comparison with other similar places I've visited before, Macau } \\
\text { is a much better destination for tourism and leisure }\end{array}$ & $3.48(0.72)$ & & & \\
\hline My choice to make this travel to Macau was a wise one & $3.69(0.79)$ & & & \\
\hline \multicolumn{5}{|l|}{ This travel experience in Macau was well worth my time and effort } \\
\hline Cognitive city image & & & 0.76 & 0.55 \\
\hline High quality of life & $3.69(0.58)$ & & & \\
\hline High technology level & $3.38(0.58)$ & & & \\
\hline Advanced education level & $3.24(0.69)$ & & & \\
\hline High wealth affective city image & $3.13(0.62)$ & & & \\
\hline Friendly people & $3.31(0.58)$ & & & \\
\hline Trustworthy people & $3.70(0.58)$ & & & \\
\hline Pleasant place & $3.54(0.64)$ & & & \\
\hline Safe environment & $3.74(0.57)$ & & & \\
\hline Destination image & & & 0.72 & 0.49 \\
\hline Attractive scenery & $3.92(0.63)$ & & & \\
\hline High-quality attractions & $3.78(0.64)$ & & & \\
\hline Lots to see and do for tourism & $3.84(0.61)$ & & & \\
\hline Well-organized tourism services & $3.34(0.72)$ & & & \\
\hline Post-visit intentions toward Macau as a tourism destination & $4.02(0.55)$ & & & \\
\hline I will surely visit Macau again in the future & $3.98(0.56)$ & & & \\
\hline
\end{tabular}

Fit statistics:

$\chi^{2}=1039.28 ; \mathrm{p}<0.001$

AGFI $=0.80 ; \mathrm{CFI}=0.92 ; \mathrm{NNFI}=0.89$

AVE: average variance extracted; AGFI: adjusted goodness-of-fit index; NNFI: non-normed fit index; CFI: comparative fit index.

Results provided adequate support to measurement choice. Although the $\chi^{2}$ value was significant $\left(\chi^{21 / 4} 1039.28 ; \mathrm{p}<\right.$ 0.001), comparative fit index (CFI 1/4 0.92) and non-normed fit index (NNFI 1/4 0.89) indicated satisfactory model fit. Moreover, all the estimated pattern coefficients of each item on their posited latent construct factors were close or above 0.50 , indicating sufficient convergent validity (Table 3). Cronbach's a ranged from 0.72 to 0.81 , suggesting 
that all the latent measures were acceptably reliable. Finally, with the exception of affective country image, for all the measures the average variance extracted reached the suggested value of 0.50 . On the basis of the above findings, it was concluded that constructs were sufficiently reliable and valid.

\section{Conclusion}

March 6, 2011, the government of the Macau special administrative region in signed the way cooperation framework agreement (hereinafter referred to as the "framework agreement") with Guangdong provincial government in Beijing, for two sides cooperation and Macau economic development, meanwhile opened up a new space and brought more opportunities for the development of Macau aviation industry. The framework agreement raised the Pearl River Delta region and the Macau SAR up to the level of national strategic cooperation, provides policy support for Macau in regional cooperation. Hong Kong-Macau-Zhuhai bridge is going to operate soon, promote the cooperation and development for three regions, is conducive to ease the pressure of the environment and airspace of third runway construction of Hong Kong international airport, and expand the development space of Macau local tourism, logistics, trade, finance, service industries etc.

In 2010, Macau international airport successfully held the third China and portuguese-speaking countries airport meeting, five copies of cooperation agreement and memorandum have been signed. Since the first meeting held in 2004, the meeting mechanism between China and the Portuguese-speaking countries airport vigorously promoted in Portugal Macau air control and airport management personnel training program of communication, give full play to the role of the mainland exchange platform with Portuguese-speaking countries. Through transport infrastructure cooperation, promote passenger transit, logistics, capital flow and information exchange, promote the development of the regional integration, to create the world tourism leisure center of energy and moderately to Macau economy development. Recently, professors of Macau civil aviation put forward a series of reform ideas, firstly is to utilize the fifth right and beyond right, to shift the Macau international airport from multifunctional small international airport to China international gate airport that connect with Portuguese-speaking countries. This idea completely conforms to the positioning of the Macau special administrative region, and closely cooperates with the "B\&R" international strategy.

Low-cost carrier (LCC) founded in the United States of America. During 1978, the Airline Deregulation Act became a Federal law that opened a new chapter for air industry since 1944 Chicago Conference. Because of the Act, LCC got a ticket on board. Southwest Airlines is the oldest and also the world's largest low-cost carrier. According to a research of United States Department of Transportation in 1993, regarding the concept of Southwest Airlines played a very powerful role of the revolution of entire air industry. With slack development trend of US airlines, English airlines as well as other European countries were also experiencing revolution and deregulation in the middle of 1980s and 1990s. A great amount of low-cost carriers filled in the market bring more options for customers also obviously raise the competition among carriers. The competition exists not only between LCCs but also could be found among low-cost carriers and full-service airlines.

The operations of Low-cost carriers are followed as: charge those services like food and beverage, check-in baggage, seats selection independently which are used to be charged as all-inclusive; increase the utilization of aircrafts; fleet may reduce maintenance cost by adopt the same mode of aircrafts; aircrew may take multiple duties, for example, cabin cleaning and security to cut down administrative expense. Besides, not every low-cost carrier is running the same way. As marketing strategy of LCC is always around keeping price low and emphasis the concept of "valuable service" at the same time. Regular routes, frequency of scheduled flights, marketing approaches and target customers would be different among various LCCs. This is the reason that consumer may not find attractive by just low prices. Also, it is not a wise move to win competition only by lower price. Since the significant influence that Southwest Airlines had brought to the entire air industry, low-cost carriers founded in European are challenging the position of major airlines progressively and gain recognition gradually in the free market. Some of the LCCs offer the same regular routes as full service airlines, while some LCCs open the new routes which are different from full service airlines in order to avoid competition and gain more market shares. At present, not just new founded LCC but subsidiaries airlines of major airlines are competing for the big cake of entire low-cost carrier industry.

Based on the field observation, major airlines in mainland China that operates the flights to Macau are Macau Airlines, Air China and Xiamen Airlines. These airlines could be found everywhere in China. However, Spring Airlines and Juneyao Airlines are the only two low-cost carriers in mainland China and set only Shanghai be the departure city. Meanwhile, all airlines which offer flights to Macau are low-cost carriers except EVA Airlines and TransAsia Airways as full service airlines. Which means low-cost carriers take a significant portion of the market in Macau; secondly, airlines including Tigerair Taiwan, Thai Smile Airways, Jin Air, Air Busan and Jetstar Airways are 
all low-cost carriers offering fights to Macau, those departure cities are all major cities in Asia, like Singapore, Manila, Gaoxiong, Taipei, Kuala Lumpur, Bangkok, Seoul, Busan and Da-Nang, etc. What is more, parts of visitors take Macau as a transfer stop other than destination; those visitors could always get lower price tickets to get to the final stop. As the rapidly grow of low-cost carrier provide even more options to fly to Macau as the transfer stop.

Macau, as a tourist city, aviation industry plays an important role, with the successful of application for the list of world heritage and exhibition industry developing in recent years, new opportunities come up for Macau aviation industry development. Relying on gaming tourism industry, the gradually developing of meeting exhibition, amusement, shopping, as a whole cultural tourism, step into diversified development. If the fifth navigation can be introduced, a real sense of "open skies", Macau aviation industry hence to break through the bottleneck of development, and touch with the new starting point--taking off.

\section{References}

Beerli, A., \& Martin, J.D. (2004a). Factors influencing destination image. Annals of Tourism Research, 31(3), 657-681.

Beerli, A., \& Martin, J.D. (2004b). Tourists' characteristics and the perceived image of tourist destination: A qualitative analysis: A case study of Lanzarote, Spain. Tourism Management, 25(5), 623-636.

Camprubi, R., Guia, J., \& Comas, J. (2014). Analyzing image fragmentation in promotional brochures: A case study of two urban destinations. Journal of Hospitality \& Tourism Research, 38(2), 135-161. http://dx.doi.org/10.1177/1096348012451451

Crompton, J. L. (1979). An Assessment of the Image of Mexico as a Vacation Destination and the Influence of Geographical Location Upon That Image. Journal of Travel Research, 17(1), 18-23. http://dx.doi.org/10.1177/004728757901700404

Deng, Q., \& Li, M. (2014). A Model of Event-Destination Image Transfer. Journal of Travel Research, 53(1), 69-82. http://dx.doi.org/10.1177/0047287513491331

Hallmann, K., Zehrer, A., \& Müller, S. (2015). Perceived Destination Image: An Image Model for a Winter Sports Destination and Its Effect on Intention to Revisit. Journal of Travel Research, 56(1), 94-106. http://dx.doi.org/10.1177/0047287513513161

Hanefors, M., \& Mossberg, L. (2002). TV travel shows: A pre-taste of the destination. Journal of Vacation Marketing, 8(3), 235-246. http://dx.doi.org/10.1177/135676670200800303

Hsu, C., \& Huang, S. (2012). An Extension of the Theory of Planned Behavior Model for Tourists. Journal of Hospitality \& Tourism Research, 36(3), 390-417. http://dx.doi.org/10.1177/1096348010390817

Hsu, C., \& Song, H. (2013). Destination image in travel magazines: A textual and pictorial analysis of Hong Kong and Macau. Journal of Vacation Marketing, 19(3), 253-268. http://dx.doi.org/10.1177/1356766712473469

Kim, H., \& Richardson, S.L. (2003). Motion picture impacts on destination images. Annals of Tourism Research, 30(1), 216-237.

Lee, B., Lee, C., \& Lee, J. (2014). Dynamic Nature of Destination Image and Influence of Tourist Overall Satisfaction on Image Modification. Journal of Travel Research, 53(2), 239-251. http://dx.doi.org/10.1177/0047287513496466

Ricart, J., \& Wang, D. (2005). Now everyone can fly: Air Asia. Asia Journal of Management Cases, 2(2), 231-255. http://dx.doi.org/10.1177/097282010500200206

Tang, L., Choi, S., Morrison, A., \& Lehto, X. (2007). The many faces of Macau: A correspondence analysis of the images communicated by online tourism information sources in English and Chinese. Journal of Vacation Marketing, 15(1), 79-94. http://dx.doi.org/10.1177/1356766708098173

Wong, I. (2013). Mainland Chinese shopping preferences and service perceptions in the Asian gaming destination of Macau. Journal of Vacation Marketing, 19(3), 239-251. http://dx.doi.org/10.1177/1356766712459737 